\title{
Pertumbuhan dan Produksi Dua Varietas Tomat (Lycopersicon esculentum Mill.) secara Hidroponik dengan beberapa Komposisi Media Tanam
}

\section{Growth and Production of Two Tomato (Lycopersicon esculentum Mill.) Varieties Hidroponically with some Growing Media Composition}

\author{
Endang Wijayanti, Anas D. Susila* \\ Departemen Agronomi dan Hortikultura, Fakultas Pertanian, Institut Pertanian Bogor \\ (Bogor Agricultural University), J1. Meranti, Kampus IPB Darmaga, Bogor 16680, Indonesia \\ Telp.\&Faks.62-251-8629353 e-mail agronipb@indo.net.id
}

\begin{abstract}
The objectives of this researchwasto determine the effect of growing media composition on growth and production of two varieties of tomatoes in a hydroponic system. The research used Randomized Complate Block Design (RCBD) with two factors, they were tomato varieties and growing media composition. The tomato varieties were (Arthaloka, Permata) and growing media compotition were 100\% husk (v/v), 75\% husk $+25 \%$ bamboo leaves compost $(v / v), 50 \%$ husks $+50 \%$ bamboo leaves compost $(v / v), 25 \%$ husk $+75 \%$ bamboo leaves compost $(v / v)$, and $100 \%$ bamboo leaves compost $(v / v)$. s. Permata variety better than Arthaloka variety, based the higher number of flower and flower bunches, number of fruit, weight of fruit and grade of fruit. Bamboo leaves compost increased heigh of plant at 2- 5 week after transplanting (WAT), number of leaves at 2 -4 WAT, number of flower at 4- 5 WAT, and 7-8 WAT, and number of flowers bunches at 5-11 WAT. The used of bamboo leaf compost $50 \%(\mathrm{v} / \mathrm{v})$ and $75 \%(\mathrm{v} / \mathrm{v})$ increased fruit number of tomato Permata variety at 7 WAT.
\end{abstract}

Keywords: rice husk, bamboo leaf compost, hydroponics, tomato production

\section{ABSTRAK}

Penelitian ini bertujuan untuk mengetahui pengaruh komposisi media tanam terhadap pertumbuhan dan produksi dua varietas tomat pada sistem hidroponik. Penelitian ini menggunakan Rancangan Kelompok Lengkap Teracak (RKLT) dengan dua faktor perlakuan, yaitu varietas dan komposisi media tanam. Faktor pertama adalah varietas (Arthaloka, Permata) dan faktor kedua adalah komposisi media tanam yang terdiri dari lima macam perlakuan yaitu $100 \%(\mathrm{v} / \mathrm{v})$ sekam, $75 \%$ sekam $+25 \%$ kompos daun bambu $(\mathrm{v} / \mathrm{v}), 50 \%$ sekam $+50 \%$ kompos daun bambu (v/v), 25\% sekam + 75\% kompos daun bambu (v/v), dan 100\% kompos daun bambu (v/v).. Vaietas Permata lebih baik dibandingkan varietas Arthaloka, berdasarkan nilai yang g lebih tinggi untuk jumlah bunga dan jumlah tandan, jumlah buah, bobot buah dan kelas buah. Kompos daun bambu meningkatkan tinggi tanaman pada umur 2 - 5 MST, jumlah daun pada 2 -4 MST, jumlah bunga pada 4 - 5 MST dan 7-8MST, jumlah tandan bunga pada 5 - 11MST. Penambahan kompos daun bambu 50\% (v/v) dan 75\% (v/v) meningkatkan jumlah buah tomat varietas Permata pada 7 MST.

Kata kunci : hidroponik, kompos daun bambu, produksi tomat, sekam

\section{PENDAHULUAN}

Tomat adalah salah satu komoditas sayuran yang diusahakan oleh petani di Indonesia. Tomat adalah sayuran yang multiguna, selain sebagai sayuran, juga

\footnotetext{
* Penulis untuk korespondensi. e-mail: anasdsusila@ymail.com
}

digunakan sebagai bahan baku industri obat-obatan dan kosmetik serta bahan baku pengolahan makanan.

Badan Pusat Statistik (2011), melaporkan bahwa produksi nasional tomat tahun 2006-2010 terus mengalami peningkatan, nilai produksinya tahun 2006 sebesar 629,744 ton, tahun 2007 sebesar 635,474 ton, tahun 2008 sebesar 725,973 ton, tahun 2009 sebesar 
853,061 ton, dan tahun 2010 sebesar 891,616 ton. Hal ini menunjukkan bahwa produksi tomat di Indonesia dapat ditingkatkan jika dilihat dari nilai produksi nasional.

Direktorat Perbenihan dan Sarana Produksi (2010) menyatakan bahwa varietas tomat yang telah dilepas oleh Menteri Pertanian sampai tahun 2006 sebanyak 54 varietas dan varietas yang sudah dilepas tersebut merupakan varietas anjuran. Varietas tomat yang telah dilepas diantaranya adalah Intan, Ratna, Berlian, Mutiara, Kaliurang, Zamrud, Opal, Arthaloka, dan Permata.

Kemampuan tomat untuk dapat menghasilkan buah sangat dipengaruhi oleh interaksi antara pertumbuhan tanaman dan kondisi lingkungan. Upaya untuk menanggulangi Penurunan kualitas dan kuantitas hasil tanaman tomat adalah dengan perbaikan teknik budidaya secara hidroponik. Harjadi (1989) menyatakan hidroponik adalah sistem budidaya yang menggunakan larutan hara dengan atau tanpa penambahan media inert seperti pasir, rockwool, atau arang sekam. Menurut Sundstrom (1982) dengan sistem hidroponik dapat diatur kondisi lingkungannya seperti suhu, kelembaban relatif dan intensitas cahaya, bahkan faktor curah hujan dapat dihilangkan sama sekali dan serangan hama penyakit dapat diperkecil.

Pendayagunaan sumberdaya sintesis seperti media tanam untuk hidroponik membuktikan peningkatan hasil tomat (Duriat, 1997). Media tanam yang baik bersifat porus dan ringan. Tujuanya agar akar tanaman tidak mudah rusak, mampu menjaga kelembaban dan menyimpan air. Arang sekam (kulit gabah) yang berwarna hitam menguntungkan sebagai media tanam, karena menghasilkan pertanaman yang baik, meminimumkan penyakit, dan ekonomis dalam penggunaan air (Zulfitri, 2005). Menurut Sutrisna dan Surdiyanti (2007), penambahan bahan organik pada pertanaman kentang meningkatkan pori tanah sehingga daya tampung tanah untuk menyimpan air juga meningkat. Penggunaan bahan organik diharapkan dapat mengurangi kebutuhan pupuk pada tanaman hidroponik.

Perbaikan sistem budidaya tomat terus dilakukan untuk meningkatkan kualitas dan kuantitas hasil. Penggunaan varietas unggul dan bahan organik diharapkan dapat meningkatkan hasil tomat baik itu dari segi kualitas maupun kuantitas. Sistem hidroponik melalui irigasi tetes merupakan cara budidaya yang akan diterapkan pada penelitian ini.

Penelitian ini bertujuan untuk mempelajari pengaruh komposisi media tanam terhadap pertumbuhan dan produksi dua varietas tomat secara hidroponik di dalam greenhouse.

\section{BAHAN DAN METODE}

Penelitian ini dilaksanakan di greenhouse Unit Lapangan Cikabayan University Farm IPB. Dramaga dengan elevasi $160 \mathrm{~m}$ diatas permukaan laut. Penelitian dilaksanakan mulai Maret sampai dengan Juli 2011.

Bahan tanaman yang digunakan adalah benih tomat varietas Arthaloka dan Permata. Casting sebagai media persemaian, arang sekam dan kompos daun bambu sebagai media tanam, furadan, insektisida. Larutan hara menggunakan pupuk $\mathrm{AB}$ Mix yang terdiri atas stock $A$ dan pupuk stock B. Stock $A$ terdiri atas $\mathrm{NH}_{4} 14 \mathrm{ppm}, \mathrm{Ca} 110 \mathrm{ppm}, \mathrm{K} 253.5 \mathrm{ppm}$, $\mathrm{Mg} 21 \mathrm{ppm}, \mathrm{NO}_{3}^{4} 150.5 \mathrm{ppm}, \mathrm{SO}_{4} 48 \mathrm{ppm}$ dan $\mathrm{H}_{2} \mathrm{PO}_{4}$ 38.75 ppm. Stock B terdiri atas Fe $0.84 \mathrm{ppm}, \mathrm{Mn}^{2} 0.55^{4}$ ppm, Zn 0.26 ppm, B 0.22 ppm, $\mathrm{Cu} 0.048$ ppm dan Mo 0.048 ppm.

Penelitian ini menggunakan Rancangan Kelompok Lengkap Teracak (RKLT) dengan dua faktor. Faktor pertama adalah varietas (Arthaloka, Permata) dan faktor kedua adalah komposisi media tanam yang terdiri atas lima jenis perlakuan yaitu $100 \%$ sekam (v/v), 75\% sekam $+25 \%$ kompos daun bambu (v/v), 50\% sekam $+50 \%$ kompos daun bambu (v/v), 25\% sekam $+75 \%$ kompos daun bambu (v/v), dan 100\% kompos daun bambu (v/v). Percobaan terdiri dari 10 kombinasi perlakuan dan 4 ulangan sehingga terdapat 40 satuan percobaan, setiap satuan percobaan terdiri dari tiga tanaman sehingga terdapat 120 tanaman.

Jarak tanam adalah double rows ukuran 0.5 m x $0.4 \mathrm{~m}$, polybag ditempatkan secara zig zag. Pengaruh varietas dan komposisi media tanam terhadap produksi tomat dapat diketahui dengan menggunakan analisis ragam. Apabila hasil analisis ragam menunjukkan pengaruh nyata, dilakukan uji lanjut Duncan Multiple Range Test (DMRT) pada taraf $5 \%$.

Benih tomat disemai dalam tray sedalam \pm $0.5 \mathrm{~cm}$ dengan media casting, ditanam satu benih per lubang Pemeliharaan cukup disiram air 2 kali/hari pada pagi dan sore hari. Bibit tomat yang telah berumur \pm 3 minggu dan dua daun telah membuka sempurna, segera dipindahkan ke polibag yang berukuran $35 \mathrm{x}$ $35 \mathrm{~cm}$. Satu polibag berisi satu bibit tomat, dan media yang digunakan untuk menanam didasarkan pada perlakuan. Melarutkan pupuk $\mathrm{AB}$ mix di dalam tangki berkapasitas 2000L. Pengecekan pengukuran $\mathrm{pH}$ dan EC larutan, nilai $\mathrm{pH}$ berkisar 6.5-6.8 dan nilai EC 2.1-2.5.

Penyulaman pada tanaman yang tidak tumbuh 
dengan bibit baru yang umurnya diperkirakan sama, dilakukan sekitar 1 MST. Pengajiran dilakukan saat tanaman berumur 4-5 MST. Pewiwilan dilakukan setiap 3 hari sekali yaitu dengan cara pemetikan tunas air pada ketiak daun, pemangkasan batang yang kurang produktif.

Untuk melindungi dari serangan hama digunakan insektisida berbahan aktif Deltamethrin dengan konsentrasi $25 \mathrm{~g} \mathrm{~L}^{-1}$. Penyiraman dilakukan secara fertigasi yaitu penyiraman bersamaan dengan pemupukan yang dilakukan melalui irigasi tetes tiap hari dari 1 MST hingga 14 MST. Penyiraman dilakukan 3 kali sehari, dengan volume $\pm 100 \mathrm{ml}$ pada umur 1-2 MST, \pm 200 pada umur 3 MST, \pm 300 $\mathrm{ml}$ pada umur 4-6 MST, $\pm 400 \mathrm{ml}$ pada umur 7-10 MST, dan 300 ml pada umur 11-14 MST.

Pemanenan mulai dilakukan pada saat tanaman berumur \pm 9 MST setelah pindah tanam. Panen dilakukan bila buah memiliki ciri warna merah (full red). Pada saat panen calyx ditinggalkan di buah. Seterusnya panen dilakukan hingga tanaman berumur \pm 14 MST.

Pengamatan dilakukan setiap minggu setelah tanaman dipindahkan ke polibag hingga buah dipanen terakhir. Pengamatan pada tanaman meliputi peubahpeubah berikut. Tinggi tanaman, diukur dari pangkal batang sampai titik tumbuh dari 1 MST sampai 5 MST. Jumlah daun dihitung dari jumlah daun yang membuka sempurna dari 1MST sampai 5 MST. Jumlah bunga dihitung dari bunga yang sudah nampak mahkotanya dari 4 MST samapai 11 MST. Jumlah tandan bunga, dihitung dari tandan bunga yang terbentuk dari 4 MST sampai 11 MST. Bunga gugur, dihitung bunga yang gugur dari percabangan dari 5 MST sampai 11 MST. Jumlah buah dihitung dari jumlah buah yang dihasilkan tiap tanaman dari 6 MST samapi 13 MST. Bobot buah per tanaman dihitung dari bobot yang dipanen pertama hingga terakhir per tanaman dari 9 MST sampai 13 MST. Diameter buah dilihat berdasarkan bobot buah dan diameter buah.

\section{HASIL DAN PEMBAHASAN}

Berdasarkan hasil uji media tanam di Laboratorium Departemen Ilmu Tanah dan Sumberdaya Lahan Faperta IPB didapatkan hasil analisis media tanam kompos daun bambu dan sekam sebagaimana disajikan pada Tabel 1. Pada tabel tersebut juga disajikan kebutuhan tanaman tomat terhadap hara secara hidroponik (Tabel 1).
Tabel 1. Kandungan unsur hara pada media tanam dan kebutuhan unsur hara tanaman tomat untuk hidroponik

\begin{tabular}{lccc}
\hline $\begin{array}{l}\text { Unsur } \\
\text { Hara }\end{array}$ & $\begin{array}{c}\text { Kompos } \\
\text { DB }\end{array}$ & Sekam & $\begin{array}{c}\text { Kebutuhan } \\
\text { Tomat untuk } \\
\text { Hidroponik }\end{array}$ \\
\hline $\mathrm{N}$ & 0.82 & 0.74 & 0.37 \\
$\mathrm{P}$ & 0.08 & 0.12 & 0.35 \\
$\mathrm{~K}$ & 0.18 & 0.30 & 0.16 \\
$\mathrm{Ca}$ & 0.05 & 0.13 & 0.51 \\
$\mathrm{Mg}$ & 0.05 & 0.07 & 1.12 \\
$\mathrm{Fe}$ & 421.5 & 87.3 & 0.01 \\
$\mathrm{Cu}$ & 1.53 & 0.49 & 0.00 \\
$\mathrm{Zn}$ & 4.54 & 3.46 & 0.00 \\
$\mathrm{Mn}$ & 46.31 & 16.13 & 0.00 \\
\hline
\end{tabular}

Keterangan : Kebutuhan hara berdasarkan panduan budidaya tanaman sayuran (Susila, 2006). Unsur C, N, P, K, Ca, Mg dalam (\%), Unsur Fe, $\mathrm{Cu}, \mathrm{Zn}, \mathrm{Mn}$ dalam ppm

Berdasarkan Tabel 1, kebutuhan unsur hara tomat secara hidroponik dapat tercukupi dari media tanam kompos daun bambu dan araang sekam. Kandungan hara $\mathrm{N}, \mathrm{Fe}, \mathrm{Cu}, \mathrm{Zn}$, dan $\mathrm{Mn}$ pada kompos daun bambu lebih tinggi dibandingkan media tanam sekam. Kandungan hara $\mathrm{P}, \mathrm{K}, \mathrm{Ca}$, dan $\mathrm{Mg}$ pada media kompos daun bambu lebih rendah dibandingkan media tanam sekam.

Pertumbuhan tomat dalam greenhouse secara umum cukup baik hingga akhir pengamatankendala pertumbuhan tanaman tomat adalah serangan hama dan penyakit. Pada fase awal penanaman terdapat serangan hama kutu kebul (Bemisia tabaci Genn.). Persentase tanaman yang terserang kutu kebul sebesar $2 \%$ dari jumlah total populasi. Pada saat memasuki fase generatif tanaman tomat terserang penyakit Tomato Yellow Leaf Curl Virus (TYLCV) atau geminivirus. Gejala yang nampak yaitu daun pucuk berkembang menjadi warna kuning, tulang daun menebal, dan daun menggulung ke atas. Persentase tanaman yang terserang geminivirus sebesar 3\% dari total varietas Permata.

Kondisi suhu di dalam greenhouse berfluktuasi antara suhu pagi, siang dan sore. Tanaman tomat memberikan respon negatif terhadap suhu di dalam greenhouse. Suhu paling tinggi terjadi pada range pukul 12.00-13.00 WIB yaitu berkisar antara 32-45 ${ }^{\circ} \mathrm{C}$, sedangkan kelembaban relatif harian (RH) paling tinggi terjadi pada range pukul 07.00-08.00 WIB yaitu berkisar antara $80-95 \%$. 


\section{Tinggi Tanaman dan Jumlah Daun}

Perlakuan varietas tidak berpengaruh nyata terhadap tinggi tanaman sampai 4 MST dan berpengaruh nyata pada 5 MST. Tinggi tanaman varietas Arthaloka nyata lebih tinggi dibandingkan varietas Permata pada 5 MST. Penggunaan media tanam berpengaruh sangat nyata terhadap tinggi tanaman mulai 2 MST. Tinggi tanaman dengan perlakuan media tanam sekam $100 \%$ nyata paling rendah dibandingkan dengan perlakuan lain.. Tidak terdapat interaksi antara varietas dan media tanam terhadap tinggi tanaman (Tabel 2).

Jumlah daun kedua varietas tidak menunjukkan perbedaan yang nyata dari 1 MST hingga 5 MST. Penggunaan media tanam berpengaruh nyata terhadap jumlah daun pada 2-4 MST. Jumlah daun pada 2 MST hingga 4 MST menunjukkan berbeda nyata) (Tabel 2).

Komposisi media tanam 100\% kompos daun bambu memberikan hasil yang lebih baik dibandingkan media tanam 100\% sekam. Media kompos daun bambu sebagai media pertumbuhan hidroponik mempunyai kemampuan aerasi, menyerap dan menahan air dengan baik karena mempunyai pori yang banyak (Asrodiah, 2005). Tidak terdapat interaksi antara varietas dan media tanam yang digunakan terhadap jumlah daun.
Jumlah Bunga, Jumlah Bunga per Tandan, dan Jumlah Bunga Gugur

Perlakuan varietas berpengaruh sangat nyata terhadap jumlah bunga (Tabel 3). Jumlah bunga varietas permata nyata lebih banyak

dibandingkan varietas Arthaloka. Jumlah bunga yang terbentuk pada varietas Permata saat umur 8 MST hingga 10 MST terus mengalami penurunan dibandingkan saat tanaman berumur 4 MST hingga 7 MST, namun mengalami peningkatan kembali ketika berumur 11 MST. Jumlah bunga yang terbentuk pada varietas Arhaloka juga mengalami penurunan ketika berumur 9 MST dan 10 MST, dan mengalami kenaikan ketika tanaman berumur 11 MST (Tabel 3).

Penggunaan media tanam berpengaruh nyata terhadap jumlah bunga pada 4-5 MST dan 7-8 MST. Jumlah bunga pada media tanam sekam $100 \%(\mathrm{v} / \mathrm{v})$ pada 4-5 MST nyata paling rendah(sedikit). Jumlah bunga dengan media tanam kompos daun bambu $100 \%(\mathrm{v} / \mathrm{v})$ pada umur 7 MST dan 8 MST nyata paling tinggi/banyak.

Pada umur 6 MST, 9 MST - 11 MST jumlah bunga tidak menunjukkan hasil yang berbeda nyata, hal ini disebabkan jumlah bunga gugur meningkat.

Penggunaan media kompos daun bambu

Tabel 2. Pengaruh varietas dan media tanam terhadap tinggi dan jumlah daun tanaman tomat

\begin{tabular}{|c|c|c|c|c|c|c|c|c|c|c|}
\hline \multirow[t]{2}{*}{ Perlakuan } & \multicolumn{5}{|c|}{ Tinggi tanaman $(\mathrm{cm})$} & \multicolumn{5}{|c|}{ Jumlah daun } \\
\hline & $1 \mathrm{MST}$ & $2 \mathrm{MST}$ & $3 \mathrm{MST}$ & $4 \mathrm{MST}$ & $5 \mathrm{MST}$ & $1 \mathrm{MST}$ & $2 \mathrm{MST}$ & $3 \mathrm{MST}$ & $4 \mathrm{MST}$ & $5 \mathrm{MST}$ \\
\hline \multicolumn{11}{|l|}{ Varietas } \\
\hline Arthaloka & 14.75 & 26.86 & 43.56 & 63.42 & $82.54 \mathrm{a}$ & 5.01 & 7.63 & 10.81 & 14.76 & 17.51 \\
\hline Permata & 14.01 & 26.8 & 43.78 & 61.32 & $74.67 \mathrm{~b}$ & 4.81 & 7.56 & 11.11 & 14.73 & 16.35 \\
\hline Uji F & tn & tn & tn & tn & * & tn & tn & tn & tn & tn \\
\hline \multicolumn{11}{|l|}{ Media Tanam (v/v) } \\
\hline Daun bambu $100 \%$ & 14.39 & $28.19 \mathrm{a}$ & $47.10 \mathrm{a}$ & $68.53 a$ & $84.60 \mathrm{a}$ & 5.12 & $8.00 \mathrm{a}$ & $11.71 \mathrm{a}$ & $16.2 \mathrm{a}$ & 18.08 \\
\hline Sekam 100\% & 13.71 & $23.61 \mathrm{~b}$ & $36.09 \mathrm{~b}$ & $50.46 \mathrm{~b}$ & $65.88 \mathrm{~b}$ & 4.7 & $7.16 \mathrm{c}$ & $10.12 b$ & $12.45 \mathrm{~b}$ & 15.58 \\
\hline $\begin{array}{l}\text { Sekam } 25 \% \text { - daun } \\
\text { bambu } 75 \%\end{array}$ & 15.1 & $28.59 \mathrm{a}$ & $46.22 \mathrm{a}$ & $64.09 \mathrm{a}$ & $80.88 \mathrm{a}$ & 4.87 & $7.79 \mathrm{ab}$ & $11.2 \mathrm{a}$ & $14.33 \mathrm{ab}$ & 16.04 \\
\hline $\begin{array}{l}\text { Sekam } 50 \% \text { - daun } \\
\text { bambu } 50 \%\end{array}$ & 14.45 & $27.49 \mathrm{a}$ & $45.72 \mathrm{a}$ & $65.54 \mathrm{a}$ & $80.32 a$ & 4.95 & 7.66abc & $11.04 \mathrm{ab}$ & $15.58 \mathrm{a}$ & 17.91 \\
\hline $\begin{array}{l}\text { Sekam } 75 \% \text { - daun } \\
\text { bambu } 25 \%\end{array}$ & 14.26 & $26.28 \mathrm{a}$ & $43.22 \mathrm{a}$ & $63.23 \mathrm{a}$ & $81.35 \mathrm{a}$ & 4.91 & $7.37 \mathrm{bc}$ & $10.75 \mathrm{ab}$ & $15.16 \mathrm{a}$ & 17.04 \\
\hline Uji-F & tn & $* *$ & $* *$ & $* *$ & $*$ & tn & $*$ & $*$ & $*$ & tn \\
\hline Interaksi & tn & tn & tn & tn & tn & tn & tn & tn & tn & tn \\
\hline
\end{tabular}

Keterangan: tn $=$ tidak berpengaruh nyata pada taraf uji $5 \%, * *=$ berpengaruh nyata pada taraf uji $1 \%, *=$ berpengaruh nyata pada taraf uji 5\%, angka pada tiap kolom yang diikuti huruf yang sama tidak berbeda nyata berdasarkan uji DMRT 5\% 
mampu meningkatkan jumlah bunga yang terbentuk. Tidak ada interaksi antara varietas dengan media tanam yang digunakan terhadap jumlah bunga. Jumlah tandan bunga yang terbentuk pada kedua varietas dari umur 4 MST hingga 11 MST sangat berbeda nyata (Tabel 4) Komposisi media tanam yang digunakan juga berpengaruh nyata pada umur 5 MST dan berpengaruh sangat nyata pada umur 6 MST hingga
11 MST, namun media tanam tidak berpengaruh nyata pada 4 MST.

Penggunaan komposisi media tanam dengan kompos daun bambu 100\% (v/v) mampu memberikan hasil yang tertinggi. Pemakaian media tanam kompos dengan perbandingan $25 \%$ kompos daun bambu (v/ v) dan $100 \%$ sekam memberikan hasil yang rendah terhadap pembentukan tandan bunga. Tidak terdapat

Tabel 3. Pengaruh varietas dan media tanam terhadap jumlah bunga per tanaman tomat

\begin{tabular}{|c|c|c|c|c|c|c|c|c|}
\hline \multirow[t]{2}{*}{ Perlakuan } & \multicolumn{8}{|c|}{ Jumlah bunga per tanaman } \\
\hline & $4 \mathrm{MST}$ & $5 \mathrm{MST}$ & $6 \mathrm{MST}$ & $7 \mathrm{MST}$ & $8 \mathrm{MST}$ & $9 \mathrm{MST}$ & $10 \mathrm{MST}$ & $11 \mathrm{MST}$ \\
\hline \multicolumn{9}{|l|}{ Varietas } \\
\hline Arthaloka & $1.14 \mathrm{~b}$ & $4.89 \mathrm{~b}$ & $7.65 b$ & $9.27 \mathrm{~b}$ & $11.61 \mathrm{~b}$ & $9.04 \mathrm{~b}$ & $7.57 b$ & $8.33 b$ \\
\hline Permata & $4.60 \mathrm{a}$ & $15.33 \mathrm{a}$ & $22.98 \mathrm{a}$ & $21.20 \mathrm{a}$ & $17.90 \mathrm{a}$ & $15.95 \mathrm{a}$ & $13.86 \mathrm{a}$ & $15.25 \mathrm{a}$ \\
\hline Uji F & $* *$ & $* *$ & $* *$ & $* *$ & $* *$ & $* *$ & $* *$ & $* *$ \\
\hline \multicolumn{9}{|l|}{ Media Tanam } \\
\hline \multicolumn{9}{|l|}{$(\% \mathrm{v} / \mathrm{v})$} \\
\hline Daun Bambu 100 & $3.64 \mathrm{ab}$ & $12.98 \mathrm{a}$ & 18.77 & $21.04 \mathrm{a}$ & $21.02 \mathrm{a}$ & 15.85 & 12.02 & 12.93 \\
\hline Sekam 100 & $1.08 \mathrm{c}$ & $5.10 \mathrm{~b}$ & 16.71 & $12.06 \mathrm{~b}$ & $11.49 b c$ & 9.68 & 8.43 & 8 \\
\hline $\begin{array}{l}\text { Sekam } 25 \text { Daun } \\
\text { Bambu } 75\end{array}$ & $4.06 \mathrm{a}$ & $11.68 \mathrm{a}$ & 14.85 & $14.95 \mathrm{ab}$ & $15.31 \mathrm{abc}$ & 13.68 & 11.06 & 16.75 \\
\hline $\begin{array}{l}\text { Sekam } 50 \text { Daun } \\
\text { Bambu } 50\end{array}$ & $3.02 \mathrm{ab}$ & $11.45 \mathrm{a}$ & 15.33 & $16.58 \mathrm{ab}$ & $16.47 \mathrm{ab}$ & 13.2 & 14.91 & 13.39 \\
\hline $\begin{array}{l}\text { Sekam } 75 \text { Daun } \\
\text { Bambu } 25\end{array}$ & $2.54 b$ & $9.33 \mathrm{a}$ & 10.91 & $11.56 \mathrm{~b}$ & $9.48 \mathrm{c}$ & 10.06 & 7.16 & 7.87 \\
\hline Respon & $* *$ & $* *$ & tn & $*$ & $* *$ & tn & tn & tn \\
\hline Interaksi & tn & tn & tn & tn & tn & tn & tn & tn \\
\hline
\end{tabular}

Keterangan : tn = tidak berpengaruh nyata pada taraf uji $5 \%, * *=$ berpengaruh nyata pada taraf uji $1 \%, *=$ berpengaruh nyata pada taraf uji $5 \%$, angka pada tiap kolom yang diikuti huruf yang sama tidak berbeda nyata berdasarkan uji DMRT 5\%

Tabel 4. Pengaruh varietas dan media tanam terhadap jumlah tandan bunga per tanaman tomat

\begin{tabular}{lcccccccc}
\hline Perlakuan & \multicolumn{7}{c}{ Jumlah tandan bunga per tanaman } \\
\cline { 2 - 8 } & $4 \mathrm{MST}$ & $5 \mathrm{MST}$ & $6 \mathrm{MST}$ & $7 \mathrm{MST}$ & $8 \mathrm{MST}$ & $9 \mathrm{MST}$ & $10 \mathrm{MST}$ & $11 \mathrm{MST}$ \\
\hline Varietas & & & & & & & & \\
Arthaloka & $0.83 \mathrm{~b}$ & $2.30 \mathrm{~b}$ & $2.12 \mathrm{~b}$ & $2.30 \mathrm{~b}$ & $3.05 \mathrm{~b}$ & $3.12 \mathrm{~b}$ & $3.33 \mathrm{~b}$ & $3.48 \mathrm{~b}$ \\
Permata & $1.90 \mathrm{a}$ & $4.55 \mathrm{a}$ & $4.87 \mathrm{a}$ & $5.32 \mathrm{a}$ & $6.01 \mathrm{a}$ & $6.46 \mathrm{a}$ & $6.94 \mathrm{a}$ & $7.09 \mathrm{a}$ \\
Uji F & $* *$ & $* *$ & $* *$ & $* *$ & $* *$ & $* *$ & $* *$ & $* *$ \\
Media Tanam (\% v/v) & & & & & & & \\
Daun Bambu 100 & 1.70 & $4.20 \mathrm{a}$ & $4.33 \mathrm{a}$ & $4.85 \mathrm{a}$ & $5.81 \mathrm{a}$ & $6.27 \mathrm{a}$ & $6.41 \mathrm{a}$ & $6.62 \mathrm{a}$ \\
Sekam 100 & 0.74 & $2.33 \mathrm{~b}$ & $2.45 \mathrm{c}$ & $2.93 \mathrm{~b}$ & $3.39 \mathrm{c}$ & $3.70 \mathrm{dc}$ & $4.02 \mathrm{bc}$ & $4.22 \mathrm{bc}$ \\
Sekam 25 Daun Bambu 75 & 1.41 & $3.52 \mathrm{ab}$ & $3.58 \mathrm{ab}$ & $3.73 \mathrm{ab}$ & $4.50 \mathrm{bc}$ & $4.87 \mathrm{bc}$ & $5.43 \mathrm{ab}$ & $5.60 \mathrm{ab}$ \\
Sekam 50 Daun Bambu 50 & 1.60 & $3.98 \mathrm{a}$ & $4.22 \mathrm{a}$ & $4.52 \mathrm{a}$ & $5.33 \mathrm{ab}$ & $5.52 \mathrm{ab}$ & $6.23 \mathrm{a}$ & $6.33 \mathrm{a}$ \\
Sekam 75 Daun Bambu 25 & 1.35 & $3.10 \mathrm{ab}$ & $2.89 \mathrm{bc}$ & $3.02 \mathrm{~b}$ & $3.62 \mathrm{c}$ & $3.60 \mathrm{~d}$ & $3.58 \mathrm{c}$ & $3.64 \mathrm{c}$ \\
Respon & tn & $*$ & $* *$ & $* *$ & $* *$ & $* *$ & $* *$ & $* *$ \\
Interaksi & tn & tn & tn & tn & tn & tn & tn & tn \\
\hline
\end{tabular}

Keterangan : th $=$ tidak berpengaruh nyata pada taraf uji $5 \%, * *=$ berpengaruh nyata pada taraf uji $1 \%$, * = berpengaruh nyata pada taraf uji $5 \%$, angka pada tiap kolom yang diikuti huruf yang sama tidak berbeda nyata berdasarkan uji DMRT $5 \%$ 
Tabel 5. Pengaruh varietas dan media tanam terhadap jumlah bunga gugur per tanaman

\begin{tabular}{|c|c|c|c|c|c|c|c|}
\hline \multirow[t]{2}{*}{ Perlakuan } & \multicolumn{7}{|c|}{ Jumlah bunga gugur per tanaman } \\
\hline & $5 \mathrm{MST}$ & $6 \mathrm{MST}$ & $7 \mathrm{MST}$ & $8 \mathrm{MST}$ & $9 \mathrm{MST}$ & $10 \mathrm{MST}$ & $11 \mathrm{MST}$ \\
\hline \multicolumn{8}{|l|}{ Varietas } \\
\hline Arthaloka & 0.64 & 1.49 & 1.66 & 0.68 & 0.46 & 0.21 & 0.16 \\
\hline Permata & 0.86 & 2.08 & 1.00 & 0.40 & 0.25 & 0.08 & 0.00 \\
\hline Uji F & tn & tn & tn & tn & tn & tn & tn \\
\hline \multicolumn{8}{|l|}{ Media Tanam (\% v/v) } \\
\hline Daun Bambu 100\% & 0.66 & 2.25 & 1.29 & 0.45 & 0.24 & 0.33 & 0.16 \\
\hline Sekam $100 \%$ & 0.50 & 1.41 & 0.95 & 0.62 & 0.41 & 0.04 & 0.04 \\
\hline Sekam 25\% Daun Bambu 75\% & 1.08 & 1.12 & 1.83 & 0.70 & 0.12 & 0.00 & 0.04 \\
\hline Sekam 50\% Daun Bambu 50\% & 0.62 & 2.12 & 1.54 & 0.12 & 0.79 & 0.29 & 0.00 \\
\hline Sekam 75\% Daun Bambu 25\% & 0.91 & 2.04 & 1.04 & 0.79 & 0.20 & 0.08 & 0.16 \\
\hline Respon & tn & tn & tn & tn & tn & tn & tn \\
\hline Interaksi & tn & tn & tn & tn & tn & tn & tn \\
\hline
\end{tabular}

Keterangan: tn $=$ tidak berpengaruh nyata pada taraf uji $5 \%, * *=$ berpengaruh nyata pada taraf uji $1 \%$, $*=$ berpengaruh nyata pada taraf uji $5 \%$, angka pada tiap kolom yang diikuti huruf yang sama tidak berbeda nyata berdasarkan uji DMRT 5\%

interaksi antara varietas yang digunakan dengan komposisi media tanam.

Suhu yang relatif tinggi dan $\mathrm{RH}$ yang relatif rendah menyebabkan bunga mudah gugur. Suhu udara di dalam greenhouse yang cenderung tinggi mengakibatkan terganggunya proses pembungaan. Jumlah bunga gugur pada kedua varietas pada 5 MST hingga 11 MST tidak menunjukkan hasil yang berbeda nyata (Tabel 5). Komposisi media tanam tidak mempengaruhi jumlah bunga gugur. Jumlah bunga gugur pada umur 6 MST dan 7 MST lebih tinggi dibandingkan pada saat tanaman berumur 5 MST, 8 MST, 9 MST, 10 MST, dan 11 MST. Hal ini disebabkan saat tanaman berumur 6 MST dan 7 MST suhu di dalam greenhouse pada siang hari meningkat mencapai angka $40-45{ }^{\circ} \mathrm{C}$ dan kelembaban relatif $(\mathrm{RH})$ di dalam greenhouse pada siang hari menurun mencapai angka $60-70 \%$.

Menurut Rubatzky dan Yamaguchi (1999) suhu siang $25-30{ }^{\circ} \mathrm{C}$ dengan suhu malam $16-20{ }^{\circ} \mathrm{C}$ adalah suhu yang optimum untuk pertumbuhan dan pembungaan. Tidak terdapat interaksi antara varietas dan media tanam yang digunakan terhadap jumlah bunga gugur.

\section{Jumlah dan Bobot Buah per Tanaman}

Jumlah buah per tanaman pada kedua varietas berbeda sangat nyata pada umur 6 MST hingga 13 MST kecuali pada umur 12 MST (Tabel 6). Penggunaan varietas Permata memberikan hasil paling tinggi dibandingkan varietas Arthaloka.
Jumlah buah terus meningkat hingga umur 11 MST, dan mengalami penurunan pada umur 12 MST. Hal ini dikarenakan pertumbuhan generatif tanaman yang terus berlangsung pada tanaman hingga umur $11 \mathrm{MST}$, sehingga jumlah buah berada pada titik maksimum pada saat tanaman berumur 11 MST. Jumlah buah terendah adalah saat tanaman berumur 12 MST, hal ini dikarenakan buah siap dipanen ketika tanaman berumur 11 MST.

Menurut Rubatzky dan Yamaguchi (1999), waktu penanaman hingga pemanenan buah pertama bergantung pada kultivar dan kondisi pertumbuhan, dan dapat berkisar dari 70 hari hingga 125 hari, sebagian besar tomat matang pada 35-60 hari setelah antesis.

Komposisi media tanam tidak berpengaruh nyata terhadap jumlah buah per tanaman nyata sejak 6 MST hingga 13 MST. Terdapat interaksi antara varietas terhadap komposisi media tanam yang digunakan pada saat tanaman berumur 7 MST. Nilai interaksi saat tanaman berumur 7 MST menunjukkan bahwa varietas Permata memberikan hasil yang berbeda cukup nyata. Penggunaan varietas Permata dengan komposisi media tanam sekam $75 \%$ - daun bambu $25 \%$ dan sekam $25 \%$ - daun bambu $75 \%$ memberikan hasil terbaik. Penggunaan media tanam sekam $100 \%$ memberikan hasil terendah.

Bobot buah per tanaman pada kedua varietas menunjukkan hasil berbeda sangat nyata pada umur 11 MST hingga 13 MST, varietas Permata menghasilkan bobot buah lebih besar dibandingkan varietas Arthaloka. Bobot buah menunjukkan hasil yang tidak 
berbeda nyata pada umur 9 MST, 10 MST, dan 12 MST (Tabel 7).

Nilai tertinggi bobot buah varietas Permata adalah saat tanaman berumur umur 11 MST yaitu sebesar 62.03 gram/tanaman. Komposisi media tanam tidak berpengaruh nyata terhadap bobot buah, , sehingga tidak terdapat perbedaan bobot buah pada semua perlakuan media tanam. Tidak terdapat interaksi antara varietas dan komposisi media tanam yang digunakan terhadap bobot buah.

\section{Grade Buah}

Grade buah merupakan faktor penting dalam menentukan standar mutu buah tomat. Tujuan penggolongan (grading) adalah menciptakan keseragaman dalam ukuran, bentuk, dan warna buah tomat. Pada penelitian ini penilaian terhadap buah tomat dilihat dari bobot dan diameter, berdasarkan varietasnya. Berdasarkan penelitian Nurtika et al. (1992), pada penelitian ini didapat hasil Grade A untuk varietas Arhaloka yaitu sebesar 2\%, Grade

Tabel 6. Pengaruh varietas dan media tanam terhadap jumlah buah per tanaman

\begin{tabular}{|c|c|c|c|c|c|c|c|c|}
\hline \multirow[t]{2}{*}{ Perlakuan } & \multicolumn{8}{|c|}{ Jumlah buah per tanaman } \\
\hline & $6 \mathrm{MST}$ & $7 \mathrm{MST}$ & $8 \mathrm{MST}$ & $9 \mathrm{MST}$ & $10 \mathrm{MST}$ & $11 \mathrm{MST}$ & $12 \mathrm{MST}$ & $13 \mathrm{MST}$ \\
\hline \multicolumn{9}{|l|}{ Varietas } \\
\hline Arthaloka & $0.15 b$ & $1.64 b$ & $4.54 b$ & $8.51 \mathrm{~b}$ & $10.38 \mathrm{~b}$ & $11.69 \mathrm{~b}$ & 1.69 & $2.65 \mathrm{~b}$ \\
\hline Permata & $2.46 \mathrm{a}$ & $5.34 \mathrm{a}$ & $10.17 \mathrm{a}$ & $15.47 \mathrm{a}$ & $19.91 \mathrm{a}$ & $20.28 \mathrm{a}$ & 1.8 & $4.83 \mathrm{a}$ \\
\hline Uji F & $* *$ & $* *$ & $* *$ & $* *$ & $* *$ & $* *$ & tn & $* *$ \\
\hline \multicolumn{9}{|l|}{ Media Tanam (\%v/v) } \\
\hline Daun Bambu 100\% & 0.93 & 3.06 & 8.93 & 15.58 & 19.97 & 20.58 & 1.7 & 3.7 \\
\hline Sekam $100 \%$ & 0.35 & 1.52 & 4.54 & 7.87 & 9.1 & 11.81 & 1.16 & 2.7 \\
\hline Sekam 25\% Daun Bambu 75\% & 2.1 & 4.66 & 7.41 & 12.02 & 16.74 & 16.43 & 1.7 & 4.6 \\
\hline Sekam 50\% Daun Bambu 50\% & 1.91 & 3.97 & 7.74 & 11.58 & 15.16 & 16.62 & 1.66 & 3.66 \\
\hline Sekam 75\% Daun Bambu 25\% & 1.22 & 4.25 & 8.14 & 12.91 & 14.75 & 14.47 & 2.5 & 4.02 \\
\hline Respon & tn & tn & tn & tn & tn & tn & tn & tn \\
\hline Interaksi & $\operatorname{tn}$ & * & tn & tn & tn & tn & tn & tn \\
\hline
\end{tabular}

Keterangan : tn $=$ tidak berpengaruh nyata pada taraf uji $5 \%, * *=$ berpengaruh nyata pada taraf uji $1 \%$, $=$ berpengaruh nyata pada taraf uji $5 \%$, angka pada tiap kolom yang diikuti huruf yang sama tidak berbeda nyata berdasarkan uji DMRT $5 \%$

Tabel 7. Pengaruh varietas dan media tanam terhadap bobot buah per tanaman (g)

\begin{tabular}{|c|c|c|c|c|c|}
\hline \multirow[t]{2}{*}{ Perlakuan } & \multicolumn{5}{|c|}{ Bobot panen buah per tanaman } \\
\hline & $9 \mathrm{MST}$ & $10 \mathrm{MST}$ & $11 \mathrm{MST}$ & $12 \mathrm{MST}$ & $13 \mathrm{MST}$ \\
\hline \multicolumn{6}{|l|}{ Varietas } \\
\hline Arthaloka & 3.65 & 29.56 & $24.45 b$ & 4.03 & $10.47 \mathrm{~b}$ \\
\hline Permata & 14.1 & 51.43 & $62.03 \mathrm{a}$ & 8.22 & $26.58 \mathrm{a}$ \\
\hline Uji F & tn & tn & $* *$ & tn & $* *$ \\
\hline \multicolumn{6}{|l|}{ Media Tanam (\%v/v) } \\
\hline Daun Bambu 100\% & 3.65 & 43.23 & 56.22 & 5.88 & 24.09 \\
\hline Sekam 100\% & 3.39 & 28.39 & 43.66 & 5.82 & 18.71 \\
\hline Sekam 25\% Daun Bambu 75\% & 28.7 & 47.69 & 45.04 & 6.95 & 19.30 \\
\hline Sekam 50\% Daun Bambu 50\% & 6.48 & 39.12 & 34.93 & 4.58 & 14.97 \\
\hline Sekam 75\% Daun Bambu 25\% & 2.16 & 44.07 & 36.34 & 7.38 & 15.57 \\
\hline Respon & tn & tn & tn & tn & tn \\
\hline Interaksi & tn & $\operatorname{tn}$ & $\operatorname{tn}$ & $\operatorname{tn}$ & $\operatorname{tn}$ \\
\hline
\end{tabular}

Keterangan : tn $=$ tidak berpengaruh nyata pada taraf uji $5 \%, * *=$ berpengaruh nyata pada taraf uji $1 \%$, * = berpengaruh nyata pada taraf uji $5 \%$, angka pada tiap kolom yang diikuti huruf yang sama tidak berbeda nyata berdasarkan uji DMRT 5\% 
Tabel 8. Grade buah tomat berdasarkan varietas

\begin{tabular}{llccc}
\hline Varietas & Grade & A & B & C \\
\hline Arthaloka & Berat (g) & $>60$ & $50-30$ & $<30$ \\
& Diameter (mm) & $>40$ & $40-30$ & $<30$ \\
& Persentase (\%) & $2 \%$ & $30 \%$ & $68 \%$ \\
Permata & Berat (g) & $>60$ & $50-30$ & $<30$ \\
& Diameter (mm) & $>40$ & $40-30$ & $<30$ \\
& Persentase (\%) & $14 \%$ & $66 \%$ & $20 \%$ \\
\hline
\end{tabular}

B untuk varietas Arthaloka sebesar 30\% dan sisanya $68 \%$ masuk kedalam grade C. Grade A untuk varietas Permata yaitu sebesar 14\%, Grade B untuk varietas Permata sebesar $66 \%$ dan sisanya $20 \%$ masuk kedalam grade $\mathrm{C}$. berdasarkan penggolongan grade, varietas Permata memiliki grade yang lebih baik dibandingkan varietas Arthaloka (Tabel 8).

Berdasarkan hasil uji media tanam, kandungan hara makro $(\mathrm{P}, \mathrm{K}, \mathrm{Ca}, \mathrm{Mg}$ ) pada sekam lebih tinggi dibandingkan kompos daun bambu. Kandungan hara mikro ( $\mathrm{Fe}, \mathrm{Cu}, \mathrm{Zn}, \mathrm{Mn}$ ) pada kompos daun bambu lebih tinggi dibandingkan sekam. Berdasarkan pertumbuhan dan hasil produksi tomat, komposisi media tanam $100 \%$ daun bambu meningkatkan tinggi tanaman pada umur 2 - 5 MST, jumlah daun pada umur 2 - 4 MST, jumlah bunga pada umur 5 MST, 7 MST, 8 MST, dan meningkatkan jumlah tandan bunga pada umur 5 MST - 11 MST. Menurut Asrodiah (2005) kompos daun bambu sebagai media tanam memiliki kemampuan aerasi, menyerap dan menahan air dengan baik karena mempunyai pori yang banyak.

Varietas Permata termasuk dalam golongan tanaman tomat dataran rendah, sedangkan varietas Arthaloka termasuk tanaman tomat dataran menengah. Kondisi ini mempengaruhi pembentukan bunga tanaman tomat. Pembentukan bunga varietas Arthaloka terhambat karena kondisi panas di dalam greenhouse. Pembentukan bunga tanaman tomat sangat bergantung pada suhu di dalam greenhouse. Suhu di dataran rendah cenderung lebih tinggi dibandingkan suhu udara di dataran tinggi. Menurut Peet dan Bartholemew (1986), suhu optimal untuk pertumbuhan dan pembungaan tomat adalah 21- 24 ${ }^{\circ} \mathrm{C}$ pada siang hari dan $18-22{ }^{\circ} \mathrm{C}$ pada malam hari.

Pada saat tanaman berumur 6 MST dan 7 MST suhu di dalam greenhouse mengalami kenaikan hingga $40-45{ }^{\circ} \mathrm{C}$ pada siang hari. Suhu yang meningkat cenderung mengakibatkan kondisi di dalam greenhouse menjadi panas. Kondisi suhu yang meningkat pada saat tanaman berumur 6 MST dan 7 MST mengakibatkan jumlah bunga gugur meningkat.
Kuo dan Tsai (1984) menyatakan suhu tinggi di daerah tropis menyebabkan rendahnya perkembangan polen, berkurangnya proses penyerbukan, hancurnya sel embrio pada putik dan rendahnya kandungan auksin dan giberelin yang dapat menghambat pembentukan buah. Harjadi (1989) menambahkan bahwa cahaya yang terlalu terik dapat meningkatkan transpirasi dan gugur bunga serta buah. Menurut Lakitan (1993) suhu sebagai faktor lingkungan dapat mempengaruhi produksi tanaman secara fisik maupun fisiologi. Secara fisik, suhu merupakan bagian yang dipengaruhi oleh radiasi sinar matahari dan dapat diestimasikan berdasarkan keseimbangan panas. Secara fisiologi, suhu dapat mempengaruhi pertumbuhan tanaman, fotosintesis, pembentukan stomata, respirasi, kelarutan zat, kecepatan reaksi, kestabilan suatu enzim dan kesetimbangan berbagai sistem lain dan persenyawaan.

Berdasarkan hasil uji media tanam, kandungan hara makro $(\mathrm{N}, \mathrm{P}, \mathrm{K}, \mathrm{Ca}, \mathrm{Mg}$ ) pada pupuk $\mathrm{AB}$ mix lebih tinggi dibandingkan kandungan hara makro pada kompos daun bambu dan sekam. Sedangkan kandungan hara mikro ( $\mathrm{Cu}, \mathrm{Zn}, \mathrm{Mn}$, $\mathrm{Fe})$ pada pupuk $\mathrm{AB}$ mix lebih rendah dibandingkan kandungan hara mikro pada kompos daun bambu dan sekam. Kandungan hara $\mathrm{C}, \mathrm{N}, \mathrm{Fe}, \mathrm{Cu}, \mathrm{Zn}$, dan $\mathrm{Mn}$ pada kompos daun bambu lebih tinggi dibandingkan media tanam sekam. Kandungan hara $\mathrm{P}, \mathrm{K}, \mathrm{Ca}$, dan $\mathrm{Mg}$ pada media kompos daun bambu lebih rendah dibandingkan media tanam sekam.

\section{KESIMPULAN}

Penggunaan tomat varietas Permata lebih unggul dibandingkan varietas Arthaloka di dalam greenhouse. Keunggulan berdasarkan pada karakter jumlah bunga pada umur 4 MST - 11 MST, jumlah tandan bunga pada umur 4 MST - 11 MST, jumlah buah pada umur 6 MST - 11 MST dan 13 MST, bobot buah pada umur 11 MST dan 13 MST, dan grade buah.

Penggunaan kompos daun bambu $100 \%(\mathrm{v} / \mathrm{v})$ sebagai media tanam hidroponik memberikan hasil yang lebih baik dibandingkan komposisi lainnya. Keunggulan berdasarkan pada karakter tinggi tanaman pada saat umur 2 MST - MST, jumlah daun pada umur 2 MST - 4 MST, jumlah bunga pada umur 5 MST, 7 MST, 8 MST, dan jumlah tandan bunga pada umur 5 MST - 11 MST.

Penambahan kompos daun bambu meningkatkan jumlah buah tomat varietas Permata pada saat tanaman berumur 7 MST. 


\section{DAFTAR PUSTAKA}

Asrodiah, R. 2005. Pemanfaatan Serasah Kompos Daun Bambu sebagai Media Pertumbuhan Stroberi (Fragaria ananassa Duch) yang Ditanam secara hidroponik. Skripsi. Jurusan Budidaya Pertanian. Fakultas Pertanian, Institut Pertanian Bogor. Bogor.

Badan Pusat Statistik. 2011. Produksi sayuran di Indonesia. http://www.bps.go.id. [14 Desember 2011]

Direktorat Perbenihan dan Sarana Produksi. 2010. Standar prosedur operasional budidaya tomat. http://www.deptan.go.id. [10 Desember 2010].

Duriat, A.S. 1997. Tomat: Komoditas andalan yang prospektif. hal 1-7. Dalam Teknologi Produksi Tomat. Duriat, A.S., Hadisoeganda, W.W., Sinaga, R.M., Hilman, Y., Basuki, R.S. Balai Penelitian Tanaman Sayuran. Bandung.

Harjadi., S.S. 1989. Dasar-Dasar Hortikultura. Jurusan Budidaya Pertanian. Institut Pertanian Bogor. Bogor.

Jones, J. Benton. 2008. Tomato Plant Culture In the Field, Greenhouse, and Home Garden $2^{\text {nd }}$ ed. Taylor \& Francis Group, LLC. U.S. Government.

Kuo, C.G., C.T. Tsai. 1984. Alternation by high temperature of high temperature of auxin and giberellin concentration in the floral buds, flower and young fruit of tomato. Hort Science. $9(6): 870-874$.

Lakitan, B. 1993. Dasar-dasar Fisiologi Tumbuhan. Raja Grafindo Persada. Jakarta.

Nurtika, N., R.E. Soeriaatmadja, E. Purwati, Nurmalinda. 1992. Perkembangan budidaya tanaman tomat di dataran tinggi Propinsi Jawa Barat. Laporan Penelitian Balai Penelitian Hortikultura. Dalam: Teknologi Produksi Tomat. Balai Penelitian Tanaman Sayuran. Bandung.

Peet, M.M, M. Bartholemew. 1986. Effect of night temperature on pollen characteristic, growth, and fruit set in tomato. J. Amer. Soc. Hort. Sci. 12(3): 514-519.

Sundstrom, A.C., 1982. Simple Hydroponics for Australian Home Gardeners. Melbourne.

Susila, A.D. 2006. Panduan Budidaya Tanaman Sayuran. Institut pertanian Bogor. Bogor.

Sutrisna, N., Y. Surdianto. 2007. Pengaruh bahan organik dan interval serta volume pemberian air terhadap pertumbuhan dan hasil kentang di rumah kaca. Jurnal Hortikultura 17(3):224236.

Zulfitri. 2005. Analisis varietas dan polybag terhadap pertumbuhan dan hasil cabai (Capsicum annum l.) sistem hidroponik. Buletin Penelitian 8. 